\title{
Serphitid wasps in Cretaceous amber from New Jersey (Hymenoptera: Serphitidae)
}

\author{
Michael S. Engel ${ }^{a, b}, *$, David A. Grimaldi ${ }^{b}$ and Jaime Ortega-Blanco ${ }^{c}$ \\ ${ }^{a}$ Division of Entomology (Paleoentomology), Natural History Museum and \\ Department of Ecology \& Evolutionary Biology, 1501 Crestline Drive - Suite 140, \\ University of Kansas, Lawrence, KS 66049-2811, USA \\ ${ }^{\mathrm{b}}$ Division of Invertebrate Zoology (Entomology), American Museum of Natural History, \\ Central Park West at 79 ${ }^{\text {th }}$ Street, New York, NY 10024-5192, USA

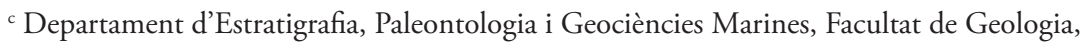 \\ Universitat de Barcelona, Martí i Franqués s/n, 08028 Barcelona, Spain \\ *Corresponding author, e-mail: msengel@ku.edu \\ Published 1 July 2011
}

\begin{abstract}
Species of the extinct, parasitoid wasp family Serphitidae (Proctotrupomorpha: Bipetiolarida: Serphitoidea), occurring in Cretaceous (Turonian) amber from New Jersey, are reviewed. Two species, both new, are described and figured as Serphites raritanensis Engel \& Grimaldi sp.n. and S. navesinkae Engel \& Grimaldi sp.n.
\end{abstract}

\section{Keywords}

Apocrita, Mesozoic, Serphites, Serphitoidea, taxonomy, amber, paleontology

\section{Introduction}

Wasps of the superfamily Serphitoidea comprise an extinct lineage preserved exclusively in amber and known from throughout the Cretaceous. The first serphitid, Serphitesparadoxus Brues, was described from two males in Late Cretaceous (Campanian) amber from Canada (Brues 1937). The family remained monospecific for the next four decades until Kozlov \& Rasnitsyn (1979) documented several species in Late Cretaceous (Santonian) amber from Siberia. These authors noted that the bipetiolate structure of the metasoma was shared with those species of the Mymarommatidae, for which they also described some Siberian amber species, and accordingly demoted mymarommatids to a subfamily within Serphitidae (as Serphitidae has priority) and considering them all as a single group within Proctotrupoidea. During the last decade numerous new specimens of Serphitidae have been recovered from Canadian (Campanian) 
amber (McKellar \& Engel 2011), as well as in new deposits from New Jersey (Turonian), Myanmar (latest Albian; Engel, data not shown) and Spain (Early Albian) (Ortega-Blanco et al. 2011a). This abundance of material and significantly expanded diversity permits a more thorough characterization of the lineage and understanding of their relationships to modern Proctotrupomorpha.

The purpose of the present contribution is to provide a brief taxonomic overview of the serphitid species in New Jersey amber (Fig. 1) so that their names are available for on-going studies of the phylogeny and evolution of Serphitoidea, along with the closely related Cretaceous, Tertiary and modern Mymarommatoidea. Keys to the genera were provided by Ortega-Blanco et al. (2011a) and McKellar \& Engel (2011). Morphological terminology follows that used elsewhere for serphitoid and mymarommatoid wasps (Kozlov \& Rasnitsyn 1979; Engel \& Grimaldi 2007; Gibson et al. 2007; OrtegaBlanco et al. 2011b). The age, geological setting, and biotic diversity of New Jersey amber is summarized by Grimaldi et al. (2000).
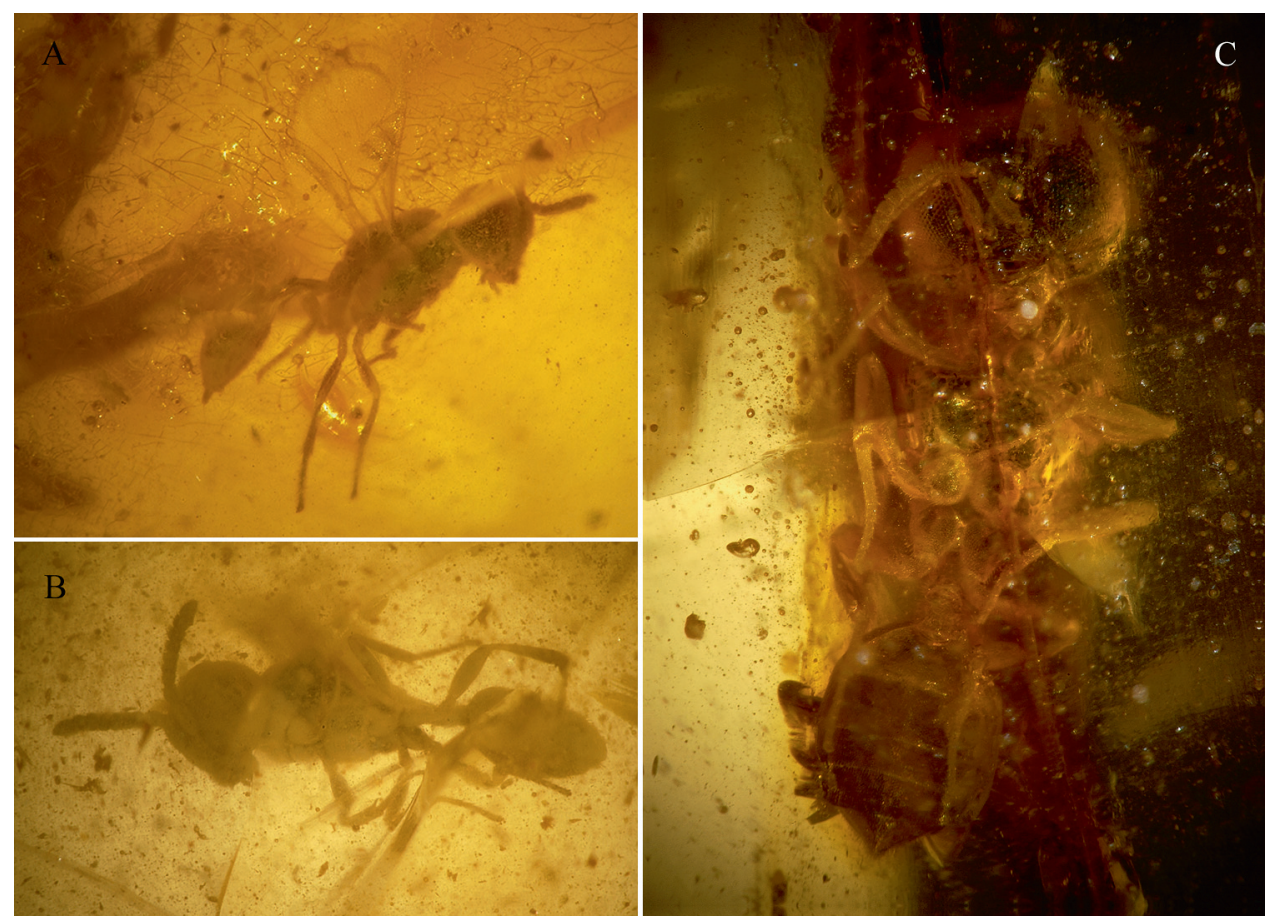

Fig. 1. Photomicrographs of New Jersey amber Serphitidae. (A) Holotype male of Serphites raritanensis Engel \& Grimaldi sp.n. (AMNH NJ-528). (B) Paratype female of S. raritanensis (AMNH NJ-1074). (C) Holotype female of $S$. navesinkae Engel \& Grimaldi sp.n. (AMNH NJ-1002d). Photomicrographs by J.O.-B. This figure is published in colour in the online edition of this journal, which can be accessed via http://www.brill.nl/ise 


\section{Systematic Palaeontology}

Family Serphitidae Brues

Genus Serphites Brues

Serphites raritanensis Engel \& Grimaldi sp.n. (Figs 1A,B, 2)

\section{Diagnosis}

Body size under $2 \mathrm{~mm}$ (S. navesinkae around $2.6 \mathrm{~mm}$, S. gigas and S. silban around $3 \mathrm{~mm}$ ); female mesepisternum without anterior areolae (present in S. navesinkae); trochantelli short (long in S. lamiak, superficially absent in S. dux and S. gigas); tarsi shorter than femora (longer in $S$. $d u x$, as long as in S. gigas and S. silban); metabasitarsus slightly shorter than combined length of remaining tarsomeres (as long as in S. lamiak, at least twice in $S$. $d u x$ ); first petiolar segment not rimmed anteriorly and petiolar segments not flattened dorsally (rimmed in S. lamiak and second segment flattened dorsally in S. paradoxus); and gaster shorter than mesosoma (as long as in $S$. dux, longer in S. gigas) and narrower than mesosoma (about as wide in S. navesinkae).

\section{Description}

Male. Body length $1.10 \mathrm{~mm}$; forewing length $0.59 \mathrm{~mm}$. Integument apparently dark brown, granulose (where evident); head not enlarged (i.e., exceptionally broad or with enlarged genae), antennae 10-segmented, with 8 flagellomeres. Forewing densely setose with longer setae around wing margin; $\mathrm{C}$ not fused to $\mathrm{Sc}+\mathrm{R}$, forming a distinct costal cell apically near pterostigma base; pterostigma triangular, approximately equilateral, with borders darker than pigmented area (Fig. 2); r-rs arising from pterostigmal midlength, slightly longer than wide; Rs strongly pigmented, not tubular, straight, reaching wing margin; $\mathrm{Rs}+\mathrm{M}$ absent; $\mathrm{M}+\mathrm{Cu}$, basal vein, and $1 \mathrm{Cu}$ tubular, other abscissae of $\mathrm{Cu}$ and $\mathrm{M}$ nebulose or absent; $1 \mathrm{~A}$ tubular proximally, becoming nebulous by apex of $1 \mathrm{Cu}$. Hind wing setose, with short setae around margin, with only $\mathrm{C}+\mathrm{Sc}+\mathrm{R}$ along anterior margin, with three apical hamuli (Fig. 2). Legs thin and long, with scattered setae; trochantelli short; femora not especially swollen, with a series of short ventroapical spicules (Fig. 2); meso- and metatibiae with two short, thin apical spurs, single protibial spur; tarsi pentamerous, with scattered setae and two apical spicules on tarsomeres; metabasitarsus slightly longer than combined length of remaining tarsomeres; pretarsal claws simple, with large arolium. Metasoma with first petiolar segment not rimmed anteriorly, about 2.7-times length of second segment; gaster shorter and narrower than mesosoma, slightly concave ventrally, with segments progressively smaller (males typically have less well developed laterotergites as is also observed in this specimen relative to the conspecific female; see also McKellar \& Engel 2011; OrtegaBlanco et al. 2011a); exposed apex of aedeagus bluntly acute, narrow.

Female. As described for the male with the following exceptions: Body length $1.45 \mathrm{~mm}$. Head without inflated genae; antennae 9-segmented, with 7 flagellomeres, 


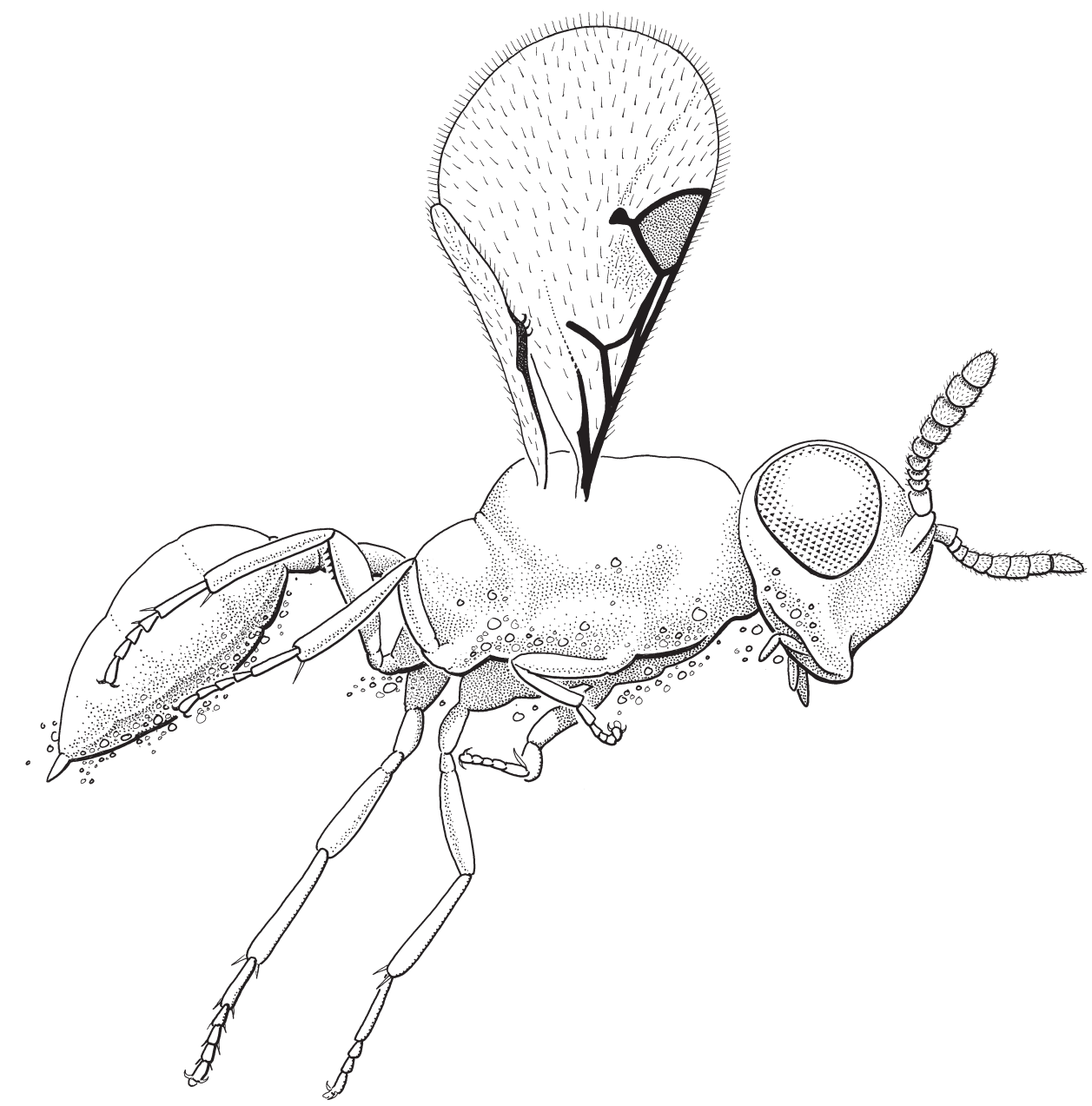

Fig. 2. Holotype male of Serphites raritanensis Engel \& Grimaldi sp.n. (AMNH NJ-528). Illustration by D.A.G.

flagellomeres slightly longer than wide, with apicalmost flagellomere distinctly longer than wide, apically tapered. Metafemur without ventroapical spicules. Mesepisternum without transverse row of distinct areolae ventroanteriorly near border with procoxa. First petiolar segment about 2.3-times as long as second petiolar segment.

\section{Holotype}

Male, NJ-528 (Fig. 1A), Late Cretaceous, New Jersey, Middlesex County, Sayreville, White Oaks pits, 1995, coll. Keith Luzzi (KL-525). Deposited in the Amber Fossil Collection, Division of Invertebrate Zoology, American Museum of Natural History, New York, NY, USA. 


\section{Paratypes}

Female, NJ-1074 (Fig. 1B), Late Cretaceous, New Jersey, Middlesex County, Sayreville, White Oaks site, Raritan Formation (Turonian), coll. K.J. \& R. Luzzi. Male, NJ-385, Late Cretaceous, New Jersey, Middlesex County, Sayreville, White Oaks pits, 1995, coll. Paul Nascimbene (PN-141). Both deposited in the Amber Fossil Collection, Division of Invertebrate Zoology, American Museum of Natural History, New York, NY, USA.

\section{Etymology}

The specific epithet refers to the geological formation from which the amber originates, the Raritan Formation.

\section{Serphites navesinkae Engel \& Grimaldi sp.n. (Figs 1C, 3)}

\section{Diagnosis}

Body size about $2.6 \mathrm{~mm}$ (under $2 \mathrm{~mm}$ in S. lamiak, S. paradoxus, S. dux, and S. raritanensis); trochantelli short; metatarsus longer than metafemur (shorter in S. lamiak, as long as in $S$. silban); metabasitarsus about as long as remaining tarsomeres combined (slightly shorter than in $S$. raritanensis); gaster shorter than mesosoma (as long in $S$. dux, longer than in S. gigas); and mesepisternum with distinct ventroanterior areolae (absent in $S$. raritanensis).

\section{Description}

Female. Body length $2.60 \mathrm{~mm}$. Integument apparently dark brown, granulose (where evident), with short, fine setae over body and legs. Head wide (Fig. 3), with slightly inflated genae; mandibles large, left mandible with bidentate apex, apex of right mandible obscured. Antenna 9-segmented (Fig. 3); flagellomeres slightly longer than wide, apicalmost flagellomere distinctly longer than wide, apically tapered. Wings obscured in holotype, the only known specimen. Legs thin and long; trochantelli short; femora not especially swollen, without ventroapical spicules; meso- and metatibiae with two short, thin apical spurs, single protibial spur; tarsi pentamerous, with scattered setae; metabasitarsus about as long as combined length of remaining tarsomeres; pretarsal claws simple, with arolium apparently reduced. Mesepisternum with transverse row of distinct areolae ventroanteriorly near border with procoxa. First petiolar segment about 2.5-times longer than second segment; gaster shorter than mesosoma, about as wide as mesosoma, ovoid in ventral aspect, 4-segmented, with strong laterotergites (Fig. 3), second gastral segment longest; sterna apparently finely imbricate.

Male. Unknown. 


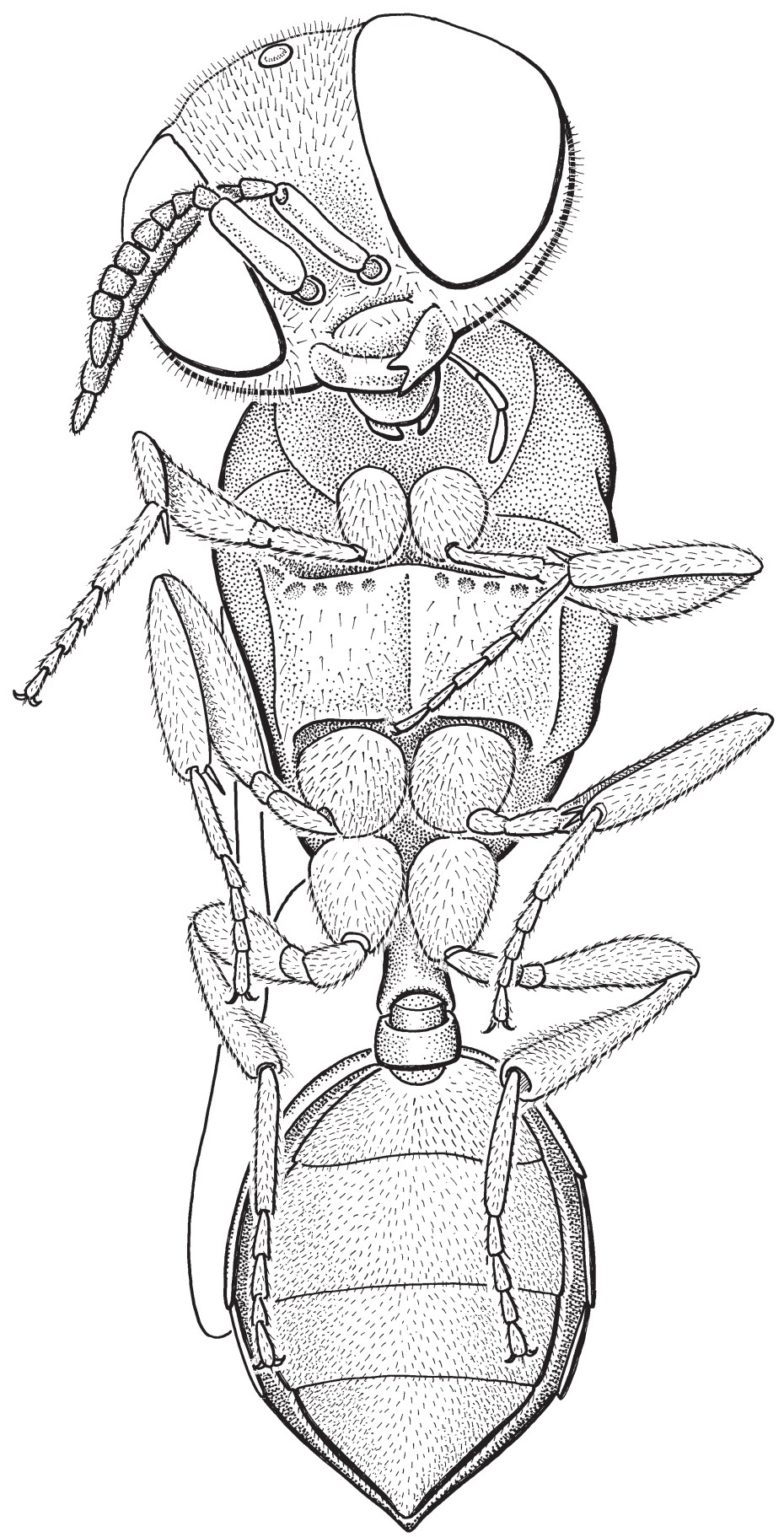

Fig. 3. Holotype female of Serphites navesinkae Engel \& Grimaldi sp.n. (AMNH NJ-1002d); drawn as preserved with left antenna slightly pulled giving the appearance of further articles but it has the same number as the right (specifically 9 articles). Illustration by D.A.G. 
Table 1. Current classification of the family Serphitidae Brues.

\begin{tabular}{|c|c|c|}
\hline Taxon & Amber deposit & Age \\
\hline \multicolumn{3}{|l|}{ Genus Aposerphites Kozlov \& Rasnitsyn 1979} \\
\hline A. angustus Ortega-Blanco et al. 2011 & Spanish & Albian \\
\hline A. solox Kozlov \& Rasnitsyn 1979 & Siberian & Santonian \\
\hline \multicolumn{3}{|l|}{ Genus Jubaserphites McKellar \& Engel 2011} \\
\hline J. ethani McKellar \& Engel 2011 & Canadian & Campanian \\
\hline \multicolumn{3}{|l|}{ Genus Microserphites Kozlov \& Rasnitsyn 1979} \\
\hline M. parvulus Kozlov \& Rasnitsyn 1979 & Siberian & Santonian \\
\hline M. soplaensis Ortega-Blanco et al. 2011 & Spanish & Albian \\
\hline \multicolumn{3}{|l|}{ Genus Serphites Brues, 1937} \\
\hline S. bruesi McKellar \& Engel 2011 & Canadian & Campanian \\
\hline S. dux Kozlov \& Rasnitsyn 1979 & Siberian & Santonian \\
\hline S. gigas Kozlov \& Rasnitsyn 1979 & Siberian & Santonian \\
\hline S. hynemani McKellar \& Engel 2011 & Canadian & Campanian \\
\hline S. kuzminae McKellar \& Engel 2011 & Canadian & Campanian \\
\hline S. lamiak Ortega-Blanco et al. 2011 & Spanish & Albian \\
\hline S. navesinkae Engel \& Grimaldi sp.n. & New Jersey & Turonian \\
\hline S. paradoxus Brues, 1937 & Canadian & Campanian \\
\hline S. pygmaeus McKellar \& Engel 2011 & Canadian & Campanian \\
\hline S. raritanensis Engel \& Grimaldi sp.n. & New Jersey & Turonian \\
\hline S. silban Ortega-Blanco et al. 2011 & Spanish & Albian \\
\hline
\end{tabular}

\section{Holotype}

Female, NJ-1002d (Fig. 1C), Late Cretaceous, New Jersey, Middlesex County, Sayreville, coll. S. Swolensky. Deposited in the Amber Fossil Collection, Division of Invertebrate Zoology, American Museum of Natural History, New York, NY, USA.

\section{Etymology}

The specific epithet honors the tribes of Navesink Native Americans who were the first inhabitants of the Sayreville, New Jersey area.

\section{Acknowledgements}

Financial support was provided by Robert G. Goelet, Chairman Emeritus of the AMNH Board of Trustees, and U.S. National Science Foundation grants EF-0341724 (to M.S.E.), DEB-0542909 (to M.S.E.), and DEB-0542726 (to D.A.G.). The participation of J.O.-B. was supported by the Ministerio de Ciencia e Innovación of Spain (through project CGL2008-00055/BTE: "The Cretaceous amber of Spain: A pluridisciplinary study", to X. Delclòs). We extend our gratitude to an anonymous reviewer and Alexandr P. Rasnitsyn for their constructive comments on the initial manuscript. This is a contribution of the Division of Entomology, University of Kansas Natural History Museum. 


\section{References}

Brues, C.T. (1937) Superfamilies Ichneumonoidea, Serphoidea, and Chalcidoidea. University of Toronto Studies, Geological Series 40: 27-44.

Engel, M.S. \& Grimaldi, D.A. (2007) New false fairy wasps in Cretaceous amber from New Jersey and Myanmar (Hymenoptera: Mymarommatoidea). Transactions of the Kansas Academy of Science 110: $159-168$.

Gibson, G.A.P., Read, J. \& Huber, J.T. (2007) Diversity, classification and higher relationships of Mymarommatoidea (Hymenoptera). Journal of Hymenoptera Research 16: 51-146.

Grimaldi, D. \& Engel, M.S. (2005) Evolution of the Insects. Cambridge University Press, Cambridge, $\mathrm{xv}+755 \mathrm{pp}$.

Grimaldi, D., Shedrinsky, A. \& Wampler, T.P. (2000) A remarkable deposit of fossiliferous amber from the Upper Cretaceous (Turonian) of New Jersey. In: Grimaldi, D. (Ed.) Studies on Fossils in Amber, with Particular Reference to the Cretaceous of New Jersey. Backhuys, Leiden, pp. 1-76.

Kozlov, M.A. \& Rasnitsyn, A.P. (1979) On the limits of the family Serphitidae (Hymenoptera, Proctotrupoidea). Entomologicheskoe Obozrenie [Revue d'Entomologie de l'URSS] 58: 402-416. [In Russian, with English summary]

McKellar, R.C. \& Engel, M.S. (2011) The serphitid wasps (Hymenoptera: Proctotrupomorpha: Serphitoidea) of Canadian Cretaceous amber. Systematic Entomology 36: 192-208.

Ortega-Blanco, J., Delclòs, X., Peñalver, E. \& Engel, M.S. (2011a) Serphitid wasps in Early Cretaceous amber from Spain (Hymenoptera: Serphitidae). Cretaceous Research 32: 143-154.

Ortega-Blanco, J., Peñalver, E., Delclòs, X. \& Engel, M.S. (2011b) False fairy wasps in Early Cretaceous amber from Spain (Hymenoptera: Mymarommatoidea). Palaeontology: in press.

Rasnitsyn, A.P. (2002) Superorder Vespida Laicharting, 1781. Order Hymenoptera Linné, 1758 (=Vespida Laicharting, 1781). In: Rasnitsyn, A.P. \& Quicke, D.L.J. (Eds.) History of Insects. Kluwer, Dordrecht, pp. $242-254$. 